\title{
NEW LIGHT ON ANOTHER SPIEGEL AFFAIR
}

\author{
BY JAMES TANIS
}

MR. TAnis, Librarian at the Andover-Harvard Theological Library, regards the Frelinghuysen Collection at the Rutgers Library as the strongest in existence. Theodorus Jacobus Frelinghuysen, a German-born émigré to New Jersey, became an important minister of the Dutch church in New Jersey.

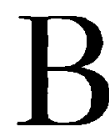

IBLIOGRAPHICAL ghosts are always a source of intrigue and frustration. Which bibliographer is content simply to let them haunt his bibliography? In attempting to prepare a more accurate list of the writings of Theodorus Jacobus Frelinghuysen, I was intrigued enough to pursue a ghost long known as Frelinghuysen's Spiegel. ${ }^{1}$

In Thomas DeWitt's "Introductory Notice" to William Demarest's edition of the sermons of Frelinghuysen he states: "It is believed that this collection of his [Frelinghuysen's] sermons contains all that he ever published." In Victor Hugo Paltsits's bio-bibliographical account of Frelinghuysen, he lists under the date I 729 a pamphlet in Dutch, Spiegel die Niet Vleyt, which he notes "is known only from its citation in the acts of the Classis of Amsterdam." This entry raises the interesting question of whether or not such a pamphlet was, indeed, ever published.

On another page, Paltsits analyzes a I 73I volume of Frelinghuysen's sermons, translated into English by Hendrik Visscher and published under the title $A$ Clear Demonstration of a Righteous and Ungodly Man in their Frame Way and End. ${ }^{4}$ Sermon III in this collection is on the text, Proverbs, chapter I4, verse I 2. The title, which he fails to note, is "A Mirrour that Flatereth not" - a reasonable translation of the sermon previously given the ap-

${ }^{1}$ Ecclesiastical Records [of the] State of New York, IV, Albany, 1902, 2457-2458.

${ }^{2}$ T. J. Frelinghuysen, Sermons, New York, 1856, p. [iii]. DeWitt, who wrote this "Introductory note," translated many Dutch texts for the Christian Intelligencer, including a rather free translation of Frelinghuysen's sermon, "De zonden der jonkheid." This sermon, which he translated from the volume Een Bundelken Leerredenen, Amsterdam, 1736, appeared in the Christian Intelligencer, 20, no. 26, [101].

${ }^{3}$ V. H. Paltsits, "A bio-bibliographical account of ... the published sermons of Theodorus Jacobus Frelinghuysen ..." in The Journal of the Rutgers University Library, 7 , no. 2,46 .

${ }^{4}$ Ibid, p. 35 .

5 T. J. Frelinghuysen, $A$ Clear Demonstration, New York, I 731 , pp. [63]-95. 
proval of the Classis of Amsterdam. It would seem at least a fair conjecture that this was, in fact, a translation of the Spiegel.

Paltsits in a footnote on this sermon remarks, "Not in Demarest, perhaps because never printed in Dutch or otherwise known in I 856." Further he notes that Demarest's translations were made "without knowing that five of the sermons had been printed by Zenger in I73r." Actually, Demarest was fully aware of this collection, for he himself notes in his edition of 1856 that there was a small collection of Frelinghuysen's sermons published in his lifetime "in the English language, accompanied with an appropriate introduction by a person by the name of "Visscher." Demarest goes on to note that "In that collection there is one sermon on a characteristic text, which is not embodied in the present volume." Earlier in that same paragraph he asserts that his collection contains all those sermons "ever published in the Dutch language." Obviously, he was unaware of any Dutch original of the "sermon on a characteristic text," though he had sermons I and II in Visscher's collection in the Dutch original $^{8}$ as well as the original volume containing Visscher's sermons IV and $V .{ }^{9}$ If Visscher ever had a printed original of the Spiegel, clearly it was not known to Demarest.

Proceeding first to the Boekzaal, a Dutch publication of the time which usually noted current theological literature, there was no sign of the Spiegel, though Frelinghuysen's Een Bundelken Leerredenen published in 1736 in Amsterdam was duly recorded. ${ }^{10}$ Turning next to Abkoude's Naamregister, ${ }^{11}$ there was not even a trace of the $I 736$ collection, so the matter was laid aside. Some time later in searching out some biographical material in Reershemius's Ostfriesländisches Prediger Denkmal (Aurich, I 765), I noted that Reershemius attributed to Frelinghuysen a pamphlet printed in Amsterdam in I 730 entitled, Spiegel die Niet en Vleidt. Here was the first conclusive evidence that a volume of some sort had, indeed,

${ }^{6}$ Paltsits, op.cit., p. 35. Though there are also many biographical errors in Paltsits's article, some of which he would have avoided had he consulted Peter Frelinghuysen's biography of $T$. J. F., no attempt can be made in this article to discuss or correct them.

${ }^{7}$ T. J. Frelinghuysen, Sermons, p. [vii].

8 These were printed in Een Trouwhertig Vertoog, Nieuw-York, 1629 [i.e. 1729].

9 These were printed in Drie Predicatien, Niew-York, 1721.

${ }^{10}$ Boekzaal Der Geleerde Wereld, Amsterdam, I 735 , pt. b, p. 739.

${ }^{11} \mathrm{~J}$. van Abkoude, Naamregister wan ... Nederduitsche boeken . . . tot het jaar

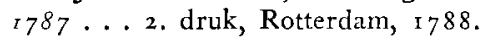


been published. But what did the lost volume include? The fact that Visscher chose only this one sermon to translate seemed to be of no consequence, for his last two sermons were chosen from a volume of three sermons, the third of which he did not include. Nor did the fact that the title of the volume was also the title of the "first" sermon seem to preclude the possible inclusion of other sermons as well. The final link was still to be found. In the early part of the I 8th Century, two Dutch booksellers, Gerrit Noordbeek and Bernardus Mourik, collaborated to produce a handy reference tool for every minister's bookshelf. ${ }^{12}$ It was a bibliography of books about the Bible arranged in biblical order, analyzing, among other things, volumes of sermons, with the information arranged by biblical text. By now I automatically looked in every index for Frelinghuysen, regardless of the purpose for which the book was first taken in hand. It was, none the less, no little surprise to see in the Register that two works of Frelinghuysen had been indexed: Een Bundelken Leer-redenen and Spiegel die Niet en Vleyd. And then on page I94, under Proverbs I4:I2, was an entry for the Spiegel. No page reference in the volume was given, indicating that the work contained no other material. At last the links were all in the chain. The sermon given approval by the Classis on 4 April I 729 had been published in Amsterdam in I $730 .{ }^{13}$ Visscher's third sermon, like the other four, was a translation from a printed text. Though the pamphlet was lost by I 856 when Demarest prepared his edition of Frelinghuysen's sermons, and though no further trace of this little volume exists in this country, or in the Netherlands, ${ }^{14}$ it is now at least certain that Frelinghuysen's Spiegel is more than a bibliographical ghost.

\footnotetext{
12 G. Noordbeek and B. Mourik, Naam-rol der Godgeleerde Schriyvers, 4. druk, Amsterdam, [ca. I 750].

${ }^{13}$ Unfortunately it was not possible to determine the printer of this tract, though it could well have been printed by Johannes Douci who later printed Frelinghuysen's Een Bundelken Leer-redenen. Douci published writings by many of the Dutch pietists, including à Brakel, d'Outrein and Lodenstein.

${ }_{14}$ In addition to consulting the Dutch National Union Catalog in the Royal Library in The Hague, I checked a number of additional smaller libraries but to no avail. In Germany the regional union catalogs were checked, as were also libraries in Westphalia where Frelinghuysen's family lived, in Lingen where he studied and in East Friesland where he pastored his first flock; but no traces were found of any of Frelinghuysen's works. Unfortunately there was not even a copy of Een Bundelken Leer-redenen in any of the libraries. Nor was the Dutch original of the sermons published in Utrecht in 1738 to be found (see Paltsits, op. cit., p. 47). Indeed the only printed i 8 th century survivor was the famous Klagte which had been published in New York in I725 (ibid., p. 45).
} 